Original Research

\title{
PREVALENCE AND RISK FACTORS OF THE ISCHEMIC HEART DISEASES IN INDONESIA: A DATA ANALYSIS OF INDONESIA BASIC HEALTH RESEARCH (RISKESDAS) 2013
}

\author{
Tati Suryati $^{1} \&$ Suyitno $^{2^{*}}$ \\ ${ }^{1}$ Puslitbang Sumber Daya dan Pelayanan Kesehatan, NIHRD, Ministry of Health of Indonesia, Indonesia \\ ${ }^{2}$ Public Health Program, STIKes Kapuas Raya, West Kalimantan, Indonesia
}

Received: 20 November 2020 | Accepted: 2 December 2020

DOI: https://dx.doi.org/10.36685/phi.v6i4.366

\author{
Correspondence: \\ Suyitno \\ STIKes Kapuas Raya, West Kalimantan, Indonesia \\ Mobile: +6281325260300 \\ Email: senopalawija@gmail.com
}

Copyright: (C) 2020 the author(s). This is an open-access article distributed under the terms of the Creative Commons Attribution Non-Commercial License, which permits unrestricted non-commercial use, distribution, and reproduction in any medium, provided the original work is properly cited.

\begin{abstract}
Background: The Cardiovascular disease (CVDs) is leading in the world as a number one cause of death. Ischemic Heart Disease (IHD) part of CVDs which is often also called coronary artery disease.

Objective: The purpose this study is to know the risk factors for ischemic heart disease in Indonesia, 2013.

Methods: The risk assessment analyzes was used to exam the risk factor IHD around 721,427 people from data of Basic Health Research (RISKESDAS) 2013 in Indonesia.

Results: The finding of this study was former smoker (Adj. OR=4.09, 95\% C.I=3.78-4.43), hypertension (Adj. OR=3.80, $95 \%$ C.I $=3.60-4.10$ ), obesity (Adj. OR=1.96, 95\% C.I=1.84-2.08), low consumption of fruits and vegetables (Adj. OR=0.70, 95\% C.I=0.57-0.87), and low physical activity (Adj. OR=1.14, 95\% C.I=1.06-1.23) are risk factor of IHD in Indonesia, 2013. Conclusion: The central, regional, and even village level special attention have a need for reducing IHD. Cross-program and sector collaboration are also needed collaboration with NGOs and the private sector to control risk factors outside the health sector and improve the environment.
\end{abstract}

Keywords: cardiovascular disease, ischemic heart disease, RISKESDAS 2013, Indonesia

\section{BACKGROUND}

Heart and blood vessel disease (cardiovascular) accounts for about half of deaths from noncommunicable disease and mostly occurs in low and middle-income countries (Benziger, Roth, \& Moran, 2016). Base on the report from WHO (World Health Organization), the Cardiovascular disease (CVDs) is leading in the world as a number one cause of death (World Health Organization, 2020a). Ischemic Heart Disease (IHD) part of CVDs which is often also called coronary artery disease is a narrowing of the blood vessels caused by the accumulation of fat, cholesterol, calcium and other substances (plaque) on the walls of blood vessels. Plaque can block blood flow and reduce oxygen supply to the heart, often causing chest pain could reducing the patient's activity and increased disability. Plaque can also cause blood clots and blocked blood flow, which can trigger a heart attack then causing death (Center for Diseases Control, 2019). 
Sustainable Development Target (SDG) 3.4 by 2030 is the reduction premature mortality of NCD by one-third from its level in 2015 . Ischemic heart disease is responsible for the highest risk of premature death in half of all countries (Countdown, 2020; Tosepu et al., 2016) and has major impact on developing countries (Sanyahumbi, Colquhoun, Wyber, \& Carapetis, 2016). Institute for Health Metric and Evaluation predicts the global incidence of people with IHD in 2015 were 7287 persons (95\% UI 6798-7808) with age standard mortality rate per 100000 : $142 \cdot 1(95 \%$ UI $139 \cdot 5$ to $145 \cdot 2)$ (Feigin, 2016).

There are two types of health summary measures in the population: health expectations (HALE) and health disparities (Schroeder, 2017). Disability-adjusted life-years (DALY) is a widely used measure of health disparities, representing the number of years of life lost (YLL) due to premature death and years of life with disabilities (YLD). DALY can be easily separated to examine the contribution of morbidity and relative mortality, individual disease, injury, and associated risk factors (Wang et al., 2016). The prediction of global DALY due to IHC is 164.0 million (95\% UI 159.6 million to 169.0 million) (Roth et al., 2017).

Epidemiological studies such as identification of risk factors in their predictive ability are very useful in disease prevention efforts. High blood pressure, high cholesterol levels, smoking; diabetes; being overweight or obese; lack of physical activity; unhealthy diet and stress are modifiable risk factors for IHD. Two risk factors for IHD, hypertension and diabetes mellitus, were predicted to have a strong association with the occurrence of unrecognized myocardial infarction (Hajar, 2017). Control of risk factors such as decreased total cholesterol (24\%), systolic blood pressure (20\%), smoking (12\%), and lack of physical activity (5\%) can reduce deaths from IHD by half (Sanchis-Gomar, PerezQuilis, Leischik, \& Lucia, 2016). Ischemic heart disease, which has the strongest association with heart failure (HF), is critical for understanding risk or predisposing factors. It should be noted that the risk factors for heart failure vary widely in different regions of the world (Paul \& Mukherjee, 2018). This study aims to determine the risk factors for coronary heart disease in Indonesia, as well as the impact if the risk factors are controlled.

\section{METHODS}

\section{Design, Population, and Sampling}

This risk assessment analyzes conducted to explore the risk factor of ischemic heart disease in Indonesia. This study used national data (RISKESDAS 2013) which had received permission from the NIHRD, Ministry of Health Indonesia. In this study ischemic heart disease is someone who has been diagnosed by a health worker with coronary heart disease, and has felt pain / discomfort in the chest, when climbing / climbing stairs or walking. The number of IHD sufferers based on the criteria in this study is around $1,492,909$ people of productive age (1664 years). After cleaning the data was only 721,427 respondents which used for the sample.

\section{Instrument}

The aged group in this study is 16-64 years old with sex male and female. Respondents who having hypertension have blood pressure $>140$ $\mathrm{mmHg}$. Respondents who are having obesity those who have the BMI $>25$. Low vegetables and fruit consumption are people who do not consume fruits and vegetables in one day. Physical activity behavior was collected data on the frequency of physical activity in the last week for residents aged $>10$ years. Measurement of physical activity is divided into 3 categories, namely heavy, moderate and light, according to WHO GPAQ 2012 and WHO STEPS 2012 standards. Consuming foods at risk are people who usually consume fast food, junk food and other foods that are at risk for IHD based on national standards and the smoking status of the respondent divided in three criteria: former smoker, smoking, and never.

\section{Data Analysis}

Descriptive, inferential, and PAR (population attributable rate) are employed to answer the research question and research hypothesis. The following statistical procedures are used to analyze the data by SPSS 15.0, NIHRD, Ministry of Health Indonesia license. 


\section{RESULTS}

The prevalence of IHD was $1.5 \%$ or equal to $1,492,909$ sufferers and $85.2 \%$ of patients were in the productive age group (15-64 years). The number of sufferers was mostly women in each age group. The graph shows that the trend of increasing cases had started at the age of 25 years and began to decline at the age of 55 years (Figure 1). Characteristics of people with coronary heart disease; Most of the female sufferers $(56.11 \%), 60.1 \%$ were workers or productive groups, and $43.3 \%$ of the sufferers did not have health insurance (such as Askes, Jamsostek, private insurance, company health benefits, Jamkesmas or Jamkesda).

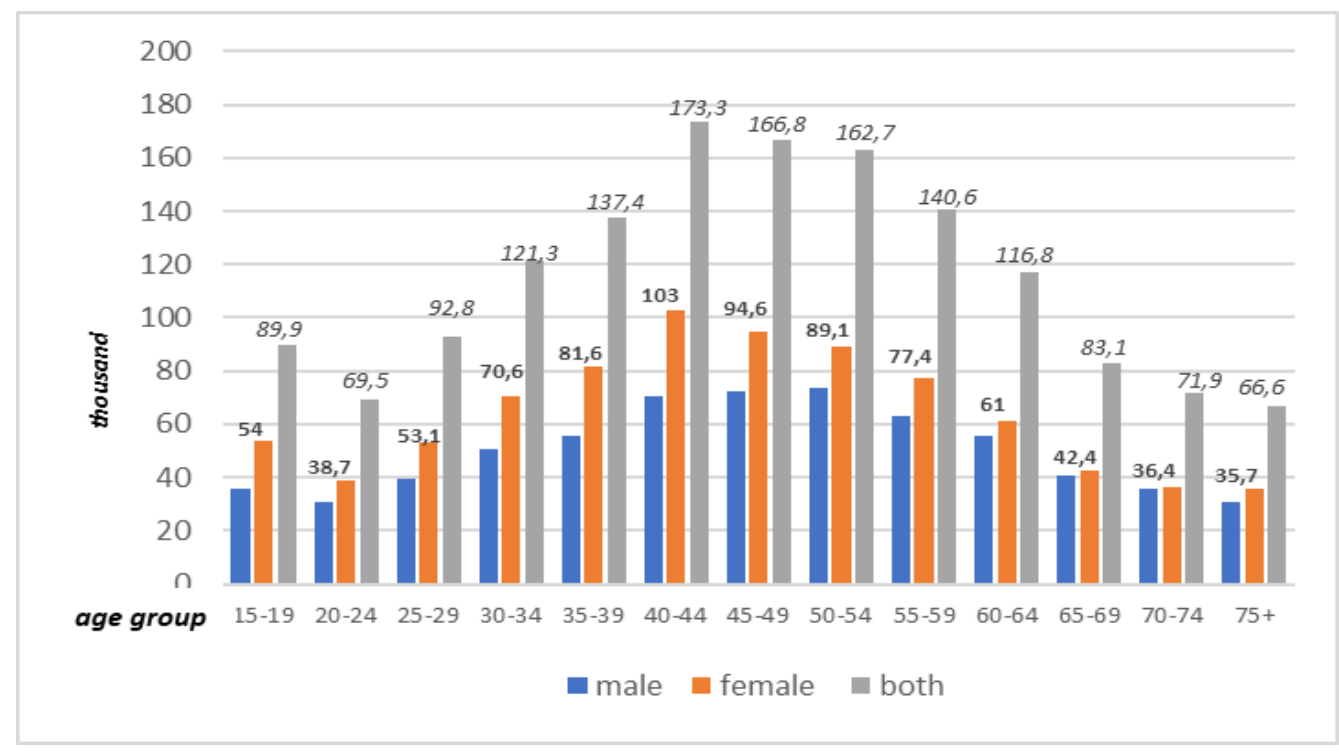

Figure 1 Overview of people with ischemic heart disease in Indonesia based on age group and gender

Table 1 The relationship between risk factor variables with ischemic heart disease in Indonesia

\begin{tabular}{|c|c|c|c|c|c|c|c|c|}
\hline \multirow[t]{2}{*}{ Variables } & \multicolumn{2}{|c|}{ IHD } & \multicolumn{2}{|c|}{ Non IHD } & \multicolumn{2}{|c|}{ Total } & \multirow[t]{2}{*}{ P value } & \multirow[t]{2}{*}{ PR $(95 \% \mathrm{CI})$} \\
\hline & $\mathrm{n}$ & $\%$ & $\mathrm{n}$ & $\%$ & $\mathrm{n}$ & $\%$ & & \\
\hline $\begin{array}{l}\text { Hypertension } \\
\text { Yes }(>140 \mathrm{mmHg}) \\
\text { No }\end{array}$ & $\begin{array}{l}2,099 \\
1,964\end{array}$ & $\begin{array}{l}1.33 \\
0.35\end{array}$ & $\begin{array}{l}155,237 \\
562,127\end{array}$ & $\begin{array}{l}98.67 \\
99.65\end{array}$ & $\begin{array}{l}157,336 \\
564,091\end{array}$ & $\begin{array}{l}100 \\
100\end{array}$ & $<0.001$ & $3.80(3.60-4.10)$ \\
\hline $\begin{array}{l}\text { Obesity } \\
\text { Yes }(\text { BMI>25) } \\
\text { No }\end{array}$ & $\begin{array}{l}1,592 \\
2,471\end{array}$ & $\begin{array}{l}0.89 \\
0.46\end{array}$ & $\begin{array}{l}177,134 \\
540,230\end{array}$ & $\begin{array}{l}99.11 \\
99.54\end{array}$ & $\begin{array}{l}178,726 \\
542,701\end{array}$ & $\begin{array}{l}100 \\
100\end{array}$ & $<0.001$ & $1.96(1.84-2.08)$ \\
\hline $\begin{array}{l}\text { Low vegetables and } \\
\text { fruit consumption } \\
\text { Yes }(<35 \text { portion } / \mathrm{mg}) \\
\text { No }\end{array}$ & $\begin{array}{c}3,973 \\
90 \\
\end{array}$ & $\begin{array}{l}0.56 \\
0.79 \\
\end{array}$ & $\begin{array}{c}706,115 \\
11,249 \\
\end{array}$ & $\begin{array}{l}99.44 \\
99.21 \\
\end{array}$ & $\begin{array}{c}710,088 \\
11,339 \\
\end{array}$ & $\begin{array}{l}100 \\
100 \\
\end{array}$ & $<0.001$ & $0.70(0.57-0.87)$ \\
\hline $\begin{array}{l}\text { Low physical activity } \\
\text { Yes }<150 \text { minute/mg) } \\
\text { No }\end{array}$ & $\begin{array}{c}3,134 \\
929 \\
\end{array}$ & $\begin{array}{l}0.58 \\
0.51 \\
\end{array}$ & $\begin{array}{l}536,150 \\
181,214 \\
\end{array}$ & $\begin{array}{l}99.42 \\
99.49 \\
\end{array}$ & $\begin{array}{l}539,284 \\
182,143 \\
\end{array}$ & $\begin{array}{l}100 \\
100\end{array}$ & $<0.001$ & $1.14(1.06-1.23)$ \\
\hline $\begin{array}{l}\text { Food at risk } \\
\text { Yes } \\
\text { No }\end{array}$ & $\begin{array}{l}2,048 \\
2,015\end{array}$ & $\begin{array}{l}0.55 \\
0.58 \\
\end{array}$ & $\begin{array}{l}370,614 \\
346,750 \\
\end{array}$ & $\begin{array}{l}99.45 \\
99.42 \\
\end{array}$ & $\begin{array}{l}372,662 \\
348,765 \\
\end{array}$ & $\begin{array}{l}100 \\
100 \\
\end{array}$ & 0.110 & $0.95(0.89-1.01)$ \\
\hline $\begin{array}{l}\text { Smoking status } \\
\text { Former smoker } \\
\text { Smoking } \\
\text { Never } \\
\end{array}$ & $\begin{array}{c}767 \\
641 \\
2,655\end{array}$ & $\begin{array}{l}2.34 \\
0.28 \\
0.57\end{array}$ & $\begin{array}{c}31,957 \\
224,415 \\
460,992 \\
\end{array}$ & $\begin{array}{l}97.66 \\
99.72 \\
99.43\end{array}$ & $\begin{array}{c}32,724 \\
225,056 \\
463,647\end{array}$ & $\begin{array}{l}100 \\
100 \\
100\end{array}$ & $<0.001$ & $\begin{array}{l}4.09(3.78-4.43) \\
0.50(0.46-0.54)\end{array}$ \\
\hline
\end{tabular}

Table 1 showed the results of the bivariate analysis of correlated risk factors $(p<0.001)$ on
IHD were: former smokers (PR 4.09), hypertension (PR 3.8) and obesity (PR 1.96). 
Former smoker has the strong correlation to increase the risk of IHD, after hypertension. With PR 4.09, it means that people who smoke only suffer from IHD 4 times compared to non- smokers. Lack of physical activity and intake of vegetables $\&$ fruits correlate with the incidence of CHD but with less significant PR.

Table 2 Combination of PAR (population attributable rate) risk factors for IHD in Indonesia in 2013

\begin{tabular}{|c|c|c|r|r|r|r|r|r|}
\hline hypertention & obese & smoker & \multicolumn{1}{c|}{ cases } & non cases & total & prevalence & \multicolumn{1}{l|}{ PR } & PAR \\
\hline (or) Yes & Yes & Yes & 3006 & 291886 & 294892 & 0.01 & 4.11 & 0.56 \\
\hline Yes & Yes & No & 2762 & 276043 & 278805 & 0.01 & 3.37 & 0.48 \\
\hline Yes & No & Yes & 2468 & 175653 & 178121 & 0.01 & 4.72 & 0.48 \\
\hline No & Yes & Yes & 2063 & 200834 & 202897 & 0.01 & 2.64 & 0.31 \\
\hline (and) Yes & Yes & Yes & 171 & 3684 & 3855 & 0.04 & 8.18 & 0.04 \\
\hline Yes & Yes & No & 929 & 56328 & 57257 & 0.02 & 3.44 & 0.16 \\
\hline Yes & No & Yes & 398 & 11541 & 11939 & 0.03 & 6.45 & 0.08 \\
\hline No & Yes & Yes & 296 & 8257 & 8553 & 0.03 & 6.55 & 0.06 \\
\hline (Reff) No & No & No & 1057 & 426535 & $0.002 * *$ & 1 & & \\
\hline Sum & & & 4063 & 717364 & $0.005 * * *$ & & & \\
\hline
\end{tabular}

In Table 2, the highest number of patients with ischemic heart disease (IHD) with a variation of only one risk factor, namely hypertension or obesity or smoking as many as 3006 cases. IHD with 3 risk factors (hypertension and obesity and smoking) there were 171 cases. The results of the PAR analysis of the combination of risk factors related to IHD showed that the intervention that combines one risk factor individually was predicted to reduce the incidence more than the intervention simultaneously. Combination of three risk factors for hypertension or obesity or smoking with PAR $56 \%$. The combination of hypertension or obesity had a PAR of $48 \%$, while the combination of hypertension or smoking had a PAR of $48 \%$ (PR 4.72). If intervening with three risk factors at once (hypertension and obesity and smoking) the chance of success in reducing IHD was high (PR 8.1), but the intervention only affects $4 \%$ of individual risk factor interventions, in smokers or with hypertension or obesity; PAR 56\% (PR 4.11).

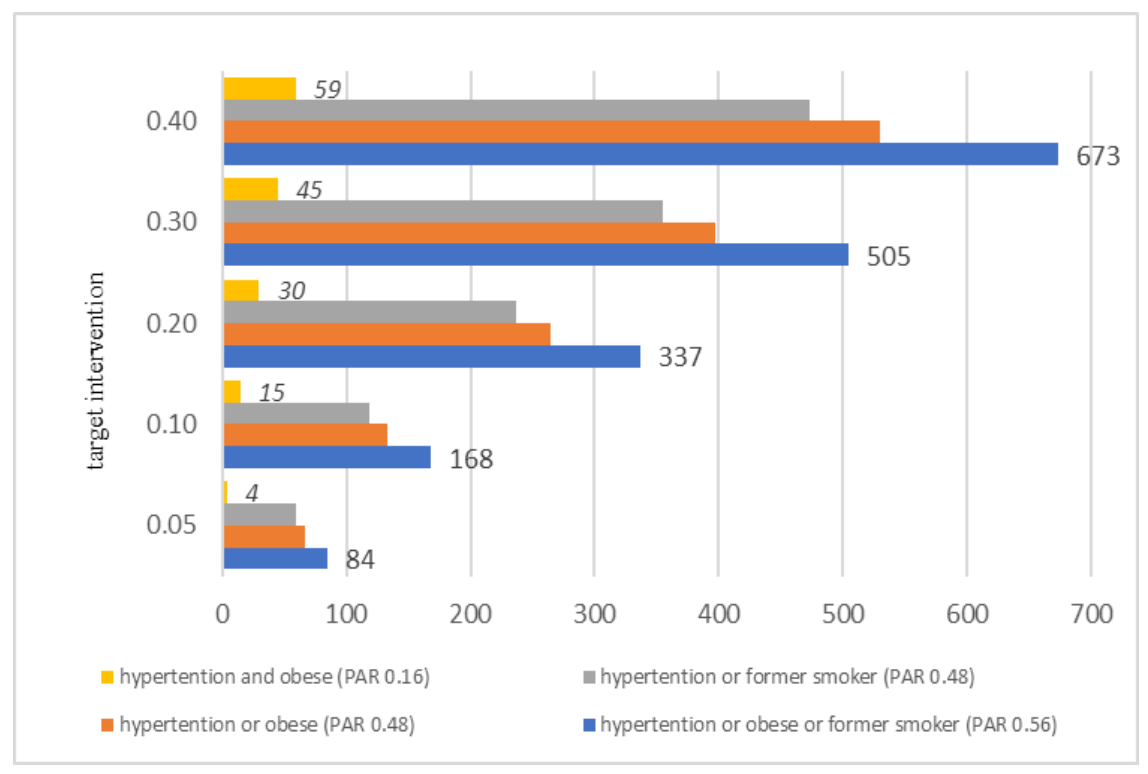

Figure 2 Predictions of reduced incidence of IHD with a variety of PAR 
Figure 2 shows the predicted reduction in the incidence of IHD with the intervention of several associated risk factors. Analyzes with various intervention targets were carried out, to see the predictive results of reducing the incidence of IHD. The results of the analysis show that the combination of risk factor intervention for hypertension or obesity or in smokers is proven to have the highest impact on reducing the incidence of IHD in Indonesia in 2013 (PAR 0.56). By planning to reduce the risk factors for hypertension or obesity or in smokers by $5 \%$, it is predicted that it will reduce the incidence of IHD by 84 people. If intervention on risk factors for hypertension or obesity, it was predicted to reduce the incidence of IHD in 66 people. Meanwhile, if the intervention is carried out on risk factors for hypertension or smoker, it is predicted that the incidence of 59 people with IHD will decrease. Intervention of two risk factors for hypertension and obesity simultaneously (PAR 0.16), proved less effective because of a small reduction in the incidence of IHD.

\section{DISCUSSION}

The results of this study indicate that former smokers have 4 times more likely to have IHD. Meanwhile, people who smoke 0.5 times the risk of getting IHD. Other studies have shown that the risk of IHD in active smokers is significantly higher than that of never smokers and smokers (Oshunbade et al., 2019). However, basically people who come into contact with cigarettes will get a loss for their physical health. Both as active and passive smokers, light smokers and heavy smokers, because tobacco is very bad for our healthy.

Although the prevalence of smokers in Indonesia tends to decline from $68.1 \%$ (Badan Statistik Pusat, 2016) and to be $62.9 \%$ (Kementerian Kesehatan Republik Indonesia, 2018) but we know that the prevalence of adolescent smoking (10-18 years) has increased by around $7.2 \%$ in 2013 (Departemen Kesehatan Republik Indonesia, 2013). It was because the growth in national cigarette sales from 2005 to 2012 has increased sharply and is in accordance with the increase in the number of smokers. The year 2005 showed the number of sales of 222 billion cigarettes and the trend continues to increase until 2012 as many as 300 billion cigarettes (Bentoel group, 2015). The impact of exposure to tobacco smoke causes IHD and other catastrophic diseases. Many researches exposed that the cost of services for smoking-related diseases is much higher than state revenue from the cigarette industry. Compared to increasing the amount of production, efforts to increase cigarette excise are considered to be more effective in increasing state revenue while simultaneously controlling tobacco consumption (World Health Organization, 2020b).

Based on this study we found whom the respondent had the hypertension status 3.8 times risk having IHD. This is in line with studies showing that hypertension is a risk factor for IHD disease in women (Ghaemian, Nabati, Saeedi, Kheradmand, \& Moosazadeh, 2020; Mehta, Wei, \& Wenger, 2015). Besides that, based on a report from Fujian, China, it also shows that hypertension is one of the main risk factors for IHD in its region (Xie et al., 2016). Therefore, it is necessary to pay special attention to the handling and inter-regional innovation programs on hypertension in the community so that it can reduce one of the risk factors for IHD.

Obesity also has a significant effect on IHD. The results of this study indicate that obese people suffer from IHD 1.9 times. It is seriously related to the incidence of IHD in various countries around the world (Cleven, Krell-Roesch, Nigg, \& Woll, 2020; Imai et al., 2019). In line with a study showing that people who have a high BMI or low aerobic fitness are associated with a higher risk of IHD and adjust for family history and socioeconomic factors (Crump, Sundquist, Winkleby, \& Sundquist, 2017). Therefore, the increase in physical activity for people in both cities and villages and applies to all age levels so that every Indonesian has an ideal body so as to reduce the level of obesity which is increasing every day. 
People who consume low vegetables and fruit consumption will have a significant risk of IHD even though they only have a PR value of 0.70 , but this also needs to be considered because what we eat will affect human emotional and physical. These results are supported by a study that confirms that consuming fruits and vegetables is a risk factor for IHD in humans (Chiu et al., 2019; Mehta et al., 2015). Therefore, the fulfillment of food intake, especially fruit and vegetables every day, needs to be supported by various parties in Indonesia. although there are abundant vegetables, people's habits need to be considered and directed to consume vegetables every day. Then is the fruit, which in Indonesia we know that the fruit will only exist according to the season. Constraints on the consumption of vegetables and fruits are very important for the health of the people in villages and cities.

The results of this study show information about Indonesian people have low PA (Physical activity) 1.14 times having risk IHD. In line with the research conducted by Cleven et al. (2020) showed information about PA (Physical activity) had a high correlation as a risk factor of IHD. With good physical activity, people will avoid hypertension and obesity because it is obvious that with good metabolism, one's mental and physical condition will also be good (Cleven et al., 2020).

The results of this study indicate that former smokers have 4 times more likely to have IHD. Meanwhile, people who smoke 0.5 times the risk of getting IHD. Other studies have shown that the risk of IHD in active smokers is significantly higher than that of never smokers and smokers (Oshunbade et al., 2019). However, basically people who come into contact with cigarettes will get a loss for their physical health. Both as active and passive smokers, light smokers and heavy smokers, because tobacco is very bad for the body.

Based on the PAR table (population attributable rate), it is found that the three priority factors for treating IHD are hypertension, obesity, and smoking. The Indonesian government needs to conduct a special study of the results of this research. Hope in the future IHD can be eliminated with innovative programs like reducing hypertension and obesity levels by increasing the physical activity of the community, and reducing the level of smokers by making wise policies on the power of cigarette companies in Indonesia.

\section{LIMITATIONS OF THE STUDY}

The RISKESDAS 2013 data was with a crosssectional design. The dependent variable for IHD patients was determined based on the respondent's admission that a doctor had diagnosed IHD and experienced several specific symptoms. Thus, while we can report the strength of the relationship between the independent and dependent variables, it cannot evaluate the causal nature of this relationship.

\section{CONCLUSION}

In sum, smoking, hypertension, obesity, low consumption of fruits and vegetables, and low physical activity are risk factors for IHD in Indonesia, 2013. It is recommended that the central, regional, and even village level special attention is needed in reducing IHD. Efforts to socialize understanding the dangers of risk factors for IHD must be started early (in adolescents and children). Cross-program and sector collaboration is needed even with NGOs and the private sector to control risk factors outside the health sector and improve the environment.

Declaration of Conflicting Interest

There is no conflict of interest to declare.

Acknowledgment

Thank you to NIHRD (National Institute Health Research Development), Ministry of Indonesia for allowing the use of RISKESDAS 2013 data for writing this article.

\section{References}

Badan Statistik Pusat. (2016). Data Susenas 2016. Jakarta (ID): Badan Pusat Statistik Indonesia.

Bentoel Group. (2015). Kajian singkat potensi dampak ekonomi industri rokok di Indonesia. Jakarta: PT. Ernst \& Young Indonesia.

Benziger, C. P., Roth, G. A., \& Moran, A. E. (2016). The global burden of disease study and the preventable burden of NCD. Global Heart, 11(4), 393-397. 
Center for Diseases Control. (2019). Coronary artery disease. Retrieved from https://www.cdc.gov/heart disease/coronary ad.htm

Chiu, Y.-H., Sandoval-Insausti, H., Ley, S. H., Bhupathiraju, S. N., Hauser, R., Rimm, E. B., . . . Chavarro, J. E. (2019). Association between intake of fruits and vegetables by pesticide residue status and coronary heart disease risk. Environment International, $132,105113$.

Cleven, L., Krell-Roesch, J., Nigg, C. R., \& Woll, A. (2020). The association between physical activity with incident obesity, coronary heart disease, diabetes and hypertension in adults: A systematic review of longitudinal studies published after 2012. BMC Public Health, 20, 1-15.

Countdown, N. (2020). NCD Countdown 2030: Pathways to achieving Sustainable Development Goal target 3.4. The Lancet.

Crump, C., Sundquist, J., Winkleby, M. A., \& Sundquist, K. (2017). Interactive effects of obesity and physical fitness on risk of ischemic heart disease. International Journal of Obesity, 41(2), 255-261.

Departemen Kesehatan Republik Indonesia. (2013). Riset kesehatan dasar. Jakarta: Badan Penelitian dan pengembangan Kesehatan Kementrian Kesehatan RI.

Feigin, V. (2016). Global, regional, and National Incidence, prevalence, and years lived with disability for 310 acute and chronic diseases and injuries, 1990-2015: A systematic analysis for the global burden of disease study 2015. The Lancet, 388(10053), 1545-1602.

Ghaemian, A., Nabati, M., Saeedi, M., Kheradmand, M., \& Moosazadeh, M. (2020). Prevalence of self-reported coronary heart disease and its associated risk factors in Tabari cohort population. BMC Cardiovascular Disorders, 20, 1-10.

Hajar, R. (2017). Risk factors for coronary artery disease: historical perspectives. Heart Views: The Official Journal of the Gulf Heart Association, 18(3), 109.

Imai, T., Miyamoto, K., Sezaki, A., Kawase, F., Shirai, Y., Abe, C., ... Shimokata, H. (2019). Traditional Japanese diet score-association with obesity, incidence of ischemic heart disease, and healthy life expectancy in a global comparative study. The Journal of Nutrition, Health \& Aging, 23(8), 717-724.

Kementerian Kesehatan Republik Indonesia. (2018). Hasil utama riset kesehatan dasar tahun 2018. Jakarta: Kementrian Kesehatan Republik Indonesia.

Mehta, P. K., Wei, J., \& Wenger, N. K. (2015). Ischemic heart disease in women: A focus on risk factors. Trends in Cardiovascular Medicine, 25(2), 140-151.

Oshunbade, A. A., Valle, K. A., Yimer, W. K., Hamid, A., Clark, D., Kamimura, D., . . B Benjamin, E. J. (2019). Cigarette smoking and incident coronary heart disease in African Americans: The Jackson Heart Study. Circulation, 140(Suppl_1), A9698-A9698.
Paul, T. K., \& Mukherjee, D. (2018). Silent myocardial infarction and risk of heart failure. Annals of Translational Medicine, 6(Suppl 1), S35

Roth, G. A., Johnson, C., Abajobir, A., Abd-Allah, F., Abera, S. F., Abyu, G., . . . Alam, K. (2017). Global, regional, and national burden of cardiovascular diseases for 10 causes, 1990 to 2015. Journal of the American College of Cardiology, 70(1), 1-25.

Sanchis-Gomar, F., Perez-Quilis, C., Leischik, R., \& Lucia, A. (2016). Epidemiology of coronary heart disease and acute coronary syndrome. Annals of Translational Medicine, 4(13), 256.

Sanyahumbi, A. S., Colquhoun, S., Wyber, R., \& Carapetis, J. R. (2016). Global disease burden of group A Streptococcus. In Streptococcus pyogenes: Basic biology to clinical manifestations [Internet]. Oklahoma: University of Oklahoma Health Sciences Center.

Schroeder, S. A. (2017). Value choices in summary measures of population health. Public Health Ethics, 10(2), 176-187.

Tosepu, R., Effendy, D. S., Bahar, H., Sakka, A., Asfian, P., \& Lestari, H. (2016). Did Indonesia achieve the MDGs goals by 2015? Public Health of Indonesia, 2(1), 1-9.

Wang, H., Naghavi, M., Allen, C., Barber, R. M., Bhutta, Z. A., Carter, A., . . . Coates, M. M. (2016). Global, regional, and national life expectancy, all-cause mortality, and cause-specific mortality for 249 causes of death, 1980-2015: A systematic analysis for the Global Burden of Disease Study 2015. The Lancet, 388(10053), 1459-1544.

World Health Organization. (2020a). Cardiovascular diseases. Retrieved from https://www.who.int/healthtopics/cardiovascular-diseases/\#tab=tab 1

World Health Organization. (2020b). Menaikkan Cukai dan harga produk tembakau untuk Indonesia sehat dan sejahtera. Retrieved from https://www.who.int/docs/ default-source/searo/indonesia/menaikkan-cukai-danharga-produk-tembakau-untuk-indonesia-sehat-dansejahtera.pdf?sfvrsn=bb058f70 2

Xie, X.-X., Zhou, W.-M., Lin, F., Li, X.-Q., Zhong, W.-L., Lin, S.-G., . . Hu, X.-J. (2016). Ischemic heart disease deaths, disability-adjusted life years and risk factors in Fujian, China during 1990-2013: Data from the Global Burden of Disease Study 2013. International Journal of Cardiology, 214, 265-269.

Cite this article as: Suryati, T., \& Suyitno. (2020). Prevalence and risk factors of the ischemic heart diseases in Indonesia: A data analysis of Indonesia basic health research (RISKESDAS) 2013. Public Health of Indonesia, 6(4), 138-144. https://dx.doi.org/10.36685/ phi.v6i4.366 